\title{
A Review of Geospatial Information of Carbon Stocks for Forestry Management, Environmental Protection and Spatial Planning: A Case Study of Southeast Sulawesi, Indonesia
}

\author{
Laode Muhammad Golok Jaya ${ }^{1}$ \\ ${ }^{1}$ Department of Information Technology, Faculty of Engineering of Halu Oleo University, Jalan HEA \\ Mokodompit, Kampus Hijau UHO Bumi Tridharma, Anduonohu-Kendari, Provinsi Sulawesi Tenggara, Indonesia \\ Correspondence: Laode Muhammad Golok Jaya, Department of Information Technology, Faculty of Engineering \\ of Halu Oleo University, Jalan HEA Mokodompit, Kampus Hijau UHO Bumi Tridharma, Anduonohu-Kendari, \\ Provinsi Sulawesi Tenggara, Indonesia. E-mail: Laodemgj@uho.ac.id
}

Received: March 5, 2020 Accepted: March 27, 2020 Online Published: June 30, 2020

\begin{abstract}
Climate change and the global warming have become an important issue at the present. Some of previous research showed the importance of studies on the sources of global warming and carbon emissions. Our attention needs to be paid to carbon monitoring worldwide. Therefore, the information about the distribution and the characteristic of carbon stocks has become very strategic matter particularly for sustainable development. This paper aims to analyze the utilization of Geospatial Information of Carbon Stocks (GICS) for forestry management, environmental protection, and spatial planning with the case study in Southeast Sulawesi, Indonesia. The method was descriptive analytic to compose several regulations related to geospatial data and information and their connetion to forestry management in Indonesia, environmental protection, and spatial planning. The results of the analysis showed that the principle of sustainable development must be supported by accurate data and information in accordance with the objectives of sustainable development. For the sustainable development, the GICS is functioning in the Strategic Environmental Assessment (SEA) and Low-Emission Development Strategy (LEDS).
\end{abstract}

Keywords: geospatial information, carbon stocks, forestry, environmental protection, regional planning, southeast sulawesi

\section{Introduction}

Carbon stocks information plays an important role in climate change mitigation and the development of a national carbon accounting system (IPCC, 2007). A study on carbon stocks leads us to understand the impact of reducing the tropical and subtropical forests, wetland, peatland, mangrove forests and savanna in terms of increasing global warming. Changes in the carbon pool due to conversion of the vegetated areas into a settlement and other cultivation areas as well as uncontrolled deforestation, forest fires, peatlands conversion and so on have a significant contribution to climate change.

The commitment of the Indonesia Government to reduce carbon emissions, especially from the forestry sector and landuse change up to $26 \%$ by the end 2020 using the common scenario (Business as Usual/BAU) and $41 \%$ with international assistance (see Figure 1) and determination to continue the reduction carbon emissions up to $85 \%$ lower than BAU in 2050 (Dewi, 2012; Dewi et al., 2012) requires a reliable Monitoring, Reporting, and Verification (MRV) method. Monitoring and estimation of carbon stocks in the framework of MRV can be performed through two methods: direct method using field survey and indirect, for instance, using remote sensing technology. Direct field survey to determine the parameters of carbon stocks in vegetation besides having advantages but more weaknesses. The advantage of the direct method is the actual value of carbon stocks obtained with a relatively good level of accuracy (Balitbang, 2013). For the Indonesian country, the estimation of carbon stocks by the direct and indirect method has been standardized through Indonesian National Standard (SNI) No. 7725: 2011 concerning the formulation of allometric equations for estimating forest carbon stocks based on ground-based forest carbon accounting (BSN, 2011). Based on the SNI, allometric models of various types (species) of trees for Indonesia's forests (Balitbang, 2013) were established and can be used to map dan monitor the carbon stocks. 


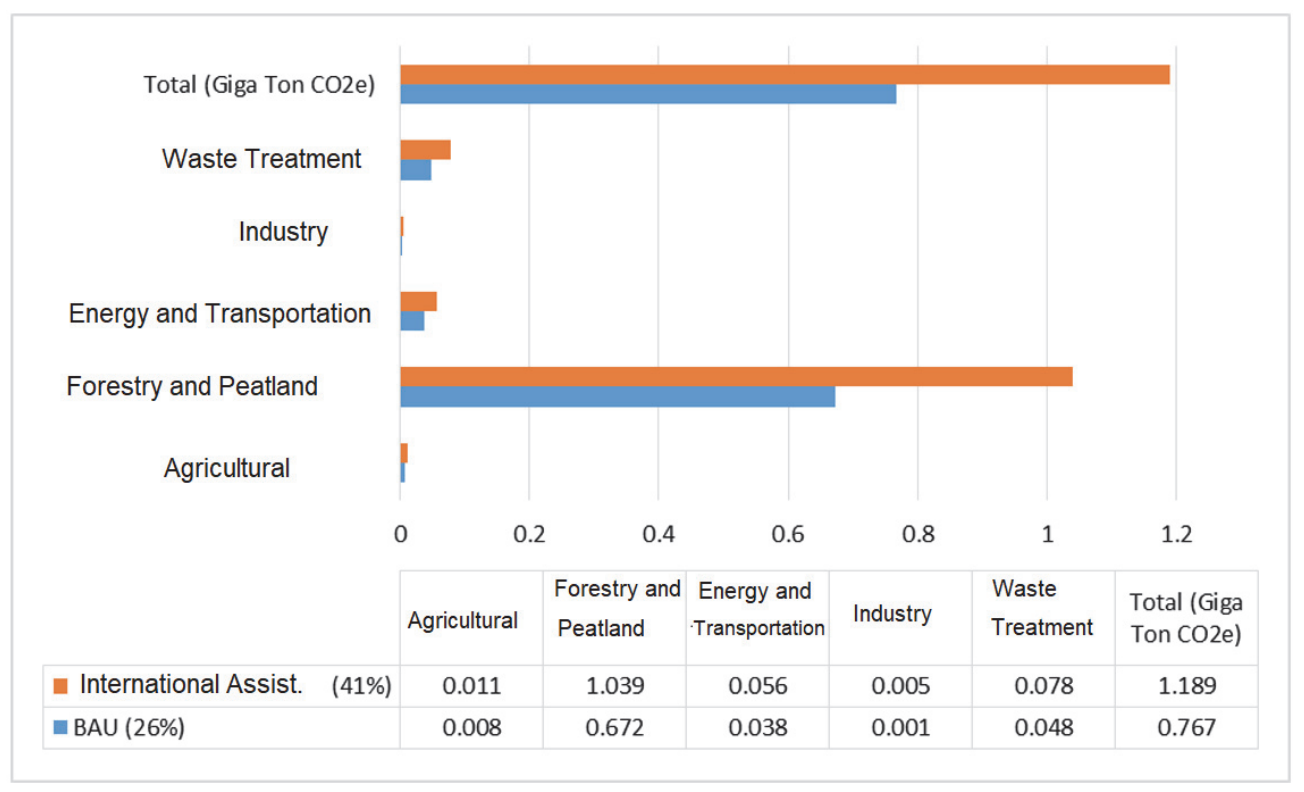

Figure 1. Scenario for reduction of carbon emission according to Indonesia Presidential Regulation (Perpres) No. 61 of 2011 concerning the National Action Plan for Reducing Greenhouse Gas (GHG) in Indonesia (Setneg RI, 2011a)

The field survey as well as remote sensing technology (optical and radar) both provide valuable data and then, by using several approaches and procedures, produce spatial information of carbon stocks. Today, we more pay attention to such information. The forestry sector, environmental protection and urban planning are several sectors that require carbon stocks information for regional development. In line with efforts to reduce emissions as resulted from deforestation and forest degradation (REDD+), it is necessary to monitor and estimate carbon stocks in a forest area to provide spatial information which is used by the authority in decision making, for example can be found in Sadaf et al (2019). However, the use of carbon stocks information for forestry sector, environmental protection and urban planning are not becoming a high priority to be used by the government although several support legislations have been established to use carbon stocks information for those sectors.

The usefulness of the geospatial information on carbon stocks can be reviewed on an international, national, and local scale (provincial or district/city). At the international scale, carbon stock information, especially in the territory of Indonesia is needed as a parameter of climate change mitigation efforts as well as climate change adaptation. By following the provisions of the Kyoto Protocol, all countries that ratify the protocol must reduce carbon emissions within a certain period. In Indonesia, the implementation of the Kyoto Protocol has been stipulated in two Presidential Regulations (Perpres), namely Perpres No. 61 of 2011 concerning the National Action Plan for Reducing Greenhouse Gas (GHG) and No. 71 of 2011 concerning the Implementation of the National Greenhouse Gas

For the national level, carbon stock information is closely related to efforts to reduce carbon emissions from various sectors, especially from the forestry sector and land use which gives the biggest contribution to carbon emissions. At the local level (Province and District/City), geospatial information on carbon stocks aims to regulate areas with High Carbon Value (HCV) such as peat, protected forests, river borders and mangroves. Regulations at the regional scale are intended to preserve the function of forests and HCV areas so that the sustainability of community life at the regional scale can be guaranteed.

In 2010, about $46 \%$ of the Sulawesi land was still coverage by tropical forests (Sumargo et al, 2011). Today, since this island becomes one of the Special Economic Zones in Indonesia, particularly the SES, the environment and the forest are facing a high threat of their sustainability. On the other hand, we realized that the local government does not yet use the spatial information properly, such as carbon stocks information, for their planning decision.

Globally, the carbon stocks information is important and becomes valuable information for the environmental analysis, forestry, disaster mitigation, spatial planning, and climate change. The decreasing of carbon stocks in a particular region is characterized by the reduction of forest cover and vegetation. It thus reduces the absorption of 
carbon dioxide by vegetation. It also reduces groundwater resources due to the loss of catchment areas. Moreover, it increases the landslide vulnerability and loss of germplasm and medical ingredients from certain vegetation species in the forest.

Since carbon stock information is closely related to space acquisition so that such information can be categorized as geospatial information. According to the Indonesia Geospatial Act (No. 4 the Year of 2011), Geospatial Data (GD) is data concerning geographical location, dimensions or size, and/or characteristics of natural and/or manmade objects that are under, on, or above the earth's surface. Whereas Geospatial Information (GI) is a GD that has been processed so that it can be used as a tool in policy formulation, decision making, and/or implementation of activities related to earth space.

This paper aims to analyze the utilization of Geospatial Information of Carbon Stocks for Forestry Management, Environmental Protection and Spatial Planning with the case study in South East Sulawesi, Indonesia. Those three sectors are very strategic in mainstreaming the use of geospatial information on carbon stocks for regional development.

\section{Method}

The study was conducted in Southeast Sulawesi (SES) Province (Figure 2). The SES is one of the 34 provinces in Indonesia which is located on Sulawesi island. Geographically, it lies between $02^{\circ} 45^{\prime}-06^{\circ} 15^{\prime} \mathrm{S}$ and $120^{\circ} 45^{\prime}-$ $124^{\circ} 30^{\prime}$ E. The province has a land area more than $38,000 \mathrm{~km}^{2}$. It is surrounded by the Banda Sea in the east and south, Bone Gulf in the west and Central Sulawesi Province in the north. Until 2019, the SES population is approximately two million people spread in the mainland and also small islands. More than one-third part of the Sulawesi island is coverage by forest.

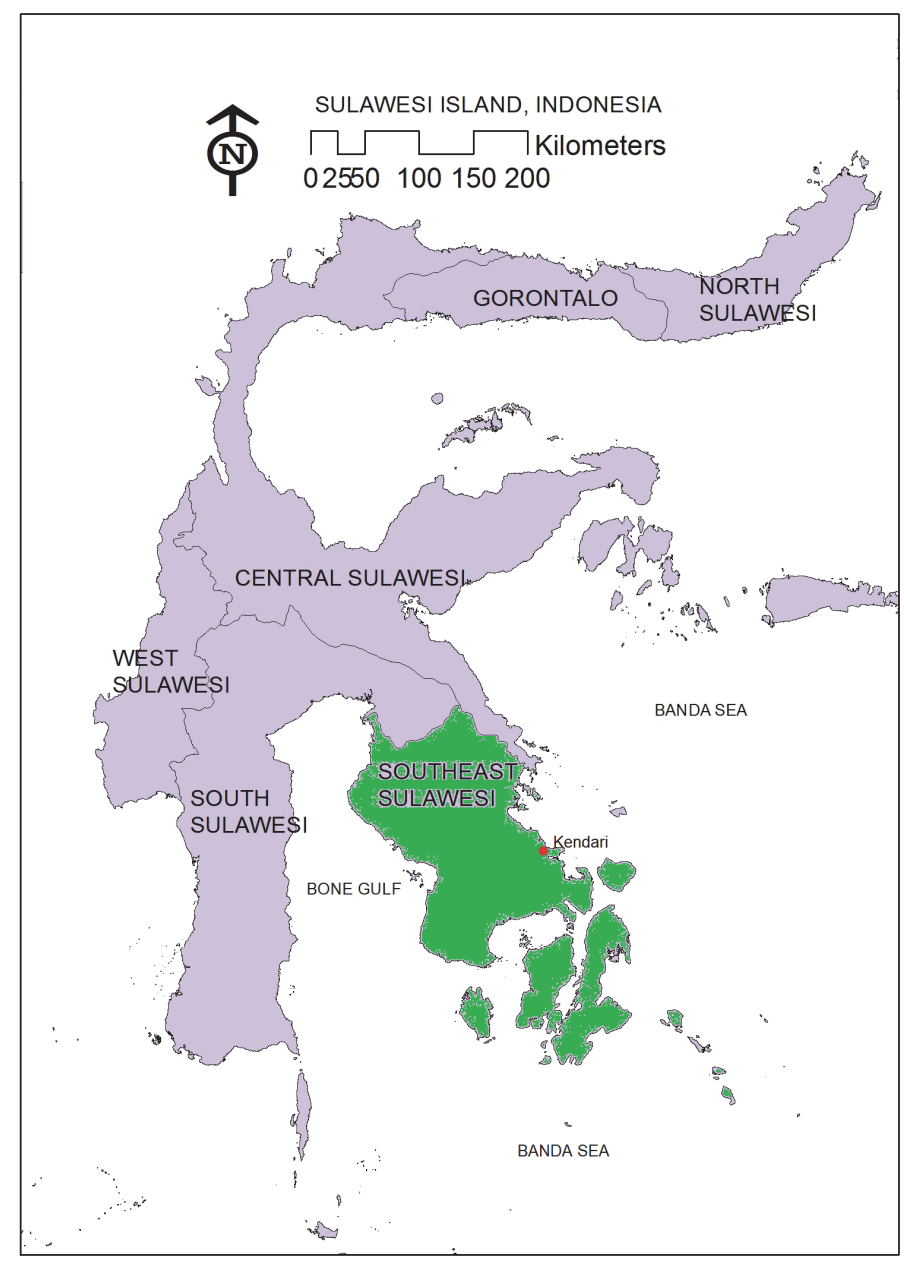

Figure 2. Study Location in Southeast Sulawesi (SES) 
SES Province was divided into 17 regencies and cities. The biggest city is Kendari which is becoming the municipality of SES. There are about fifty small islands in this province and most of these islands are inhabited.

This paper uses a descriptive analytics approach to compose the connection of the three sectors mentioned previous with Indonesia Geospatial Act 2011. Several regulations related to forestry management in Indonesia, environmental protection and spatial planning were analyzed to obtain a comprehensive view and how the connection with SEA and LEDS for sustainable development.

Carbon stock information comes from carbon stock data. Requirements for carbon stock data to produce geospatial information have been met and are in line with what is stated in the Geospatial Act in Article 27, which states that GD is collected by surveying using an instrument and/or data recorder, which are carried out on land, water, or on the air using vehicles, and/or on a spacecraft, enumeration and/or other ways by following the development of science and technology. The collection of GD must be carried out in accordance with standards that include geospatial reference system, data types, definitions, criteria, and formats.

Table 1 described the acquisition of carbon stocks data using several approaches, the spatial reference system, and data format. Based on the description it can be concluded that the carbon stock information obtained from satellite data has fulfilled the requirements to be declared as geospatial information because the survey method is derived from air vehicles (optical and radar spaceborne).

The important thing to be conveyed in this analysis is that geospatial information on carbon stocks can be used as a tool in the formulation of policies, decision making, and/or implementation of activities related to earth space. In Article 51 of the Geospatial Act it is stated that Government Agencies and Regional Governments must use an accurate GI in decision making and/or policy decisions relating to terrestrial space. Implicit carbon geospatial information should be used in decision making and/or policymaking. However, the accuracy of geospatial information on carbon stocks must be well considered.

Table 1. Characteristics of carbon stocks acquisition based on Indonesia Geospatial Act No. 4 the Year of 2011

\begin{tabular}{lll}
\hline Regulation Component & Description & Example \\
\hline Survey method & Using measurement instrument & $\begin{array}{l}\text { Measurement of Diameter at Breast Height } \\
\text { (DBH) directly in the field }\end{array}$ \\
& Land platform & $\begin{array}{l}\text { Terrestrial Laser Scanner } \\
\text { Optical and radar airborne }\end{array}$ \\
& Airborne platform & Optical and radar satellite \\
& Spaceborne platform & Stand tree coordinate, platform coordinate \\
Geospatial & reference & World Geodetic System (WGS) \\
system & 1984 Datum, Proyeksi UTM & \\
(Universal Transverse Mercator) & & \\
Data format & Optical & Optical image ie. GeoTIFF \\
& Radar & Radar image in the interferometric phase \\
\hline
\end{tabular}

\section{The Usage of Geospatial Information of Carbon Stocks (GICS)}

This section provides a literature review regarding the usage of Geospatial Information of Carbon Stocks (GICS). It begins with sub-section about the usage of GICS in the sector of forestry management. It provides some informations about the Land Use and Land Cover Change (LULCC) due to mining activity in the SES. The next sub section talks about the usage of GICS in the environmental protection sector while the last sub-section provides the relation between the GICS with spatial planning.

\subsection{Forestry Management}

The forestry sector is very interested in GICS for forest planning, land rehabilitation and REDD activities. Perpres No. 71 of 2011 concerning the Greenhouse Gas Inventory shows that the forestry sector is the largest contributor to GHG emissions, but at the same time also has the opportunity to become the largest GHG absorber. GICS can provide information on whether forests function as carbon emitters or carbon sinks.

In SE Sulawesi, the forestry sector becomes a strategic sector to be developed for social welfare. However, at the same time it contributes to GHG. In South Konawe Regency for example, forestry becomes the main source of 
GHG emission from land use and land cover change (LULCC). According to South Konawe Regency Statistic data (2010), the LULCC of the forest cover in the period 2006-2015 there has been a reduction in the area of forest cover to other land use. Figure 3 shows reducing forests to other landuse. Protected forest was reduced from 54,525 ha in 2006 to 44,251 ha in 2015 or reduced about 18.84\%. Mangrove forests were reduced from 15,963 ha in 2006 to $9,101.98$ ha in 2015 or decreased by $42.98 \%$. Furthermore, tourism forests also decreased by about $2 \%$, from 79,172 ha in 2006 to be 77,588 ha in 2015. Likewise, ordinary production forests also reducted from 160,592 ha in 2006 to 65,017 ha in 2015 or reduced by $59,51 \%$. On the other side, the other land use increased from 218,105 ha in 2006 to 260,857 ha in 2015 or increased by $19.6 \%$. Figure 3 shows the LULCC in South Konawe Regency according to statistic agency from 2010 to 2015 .

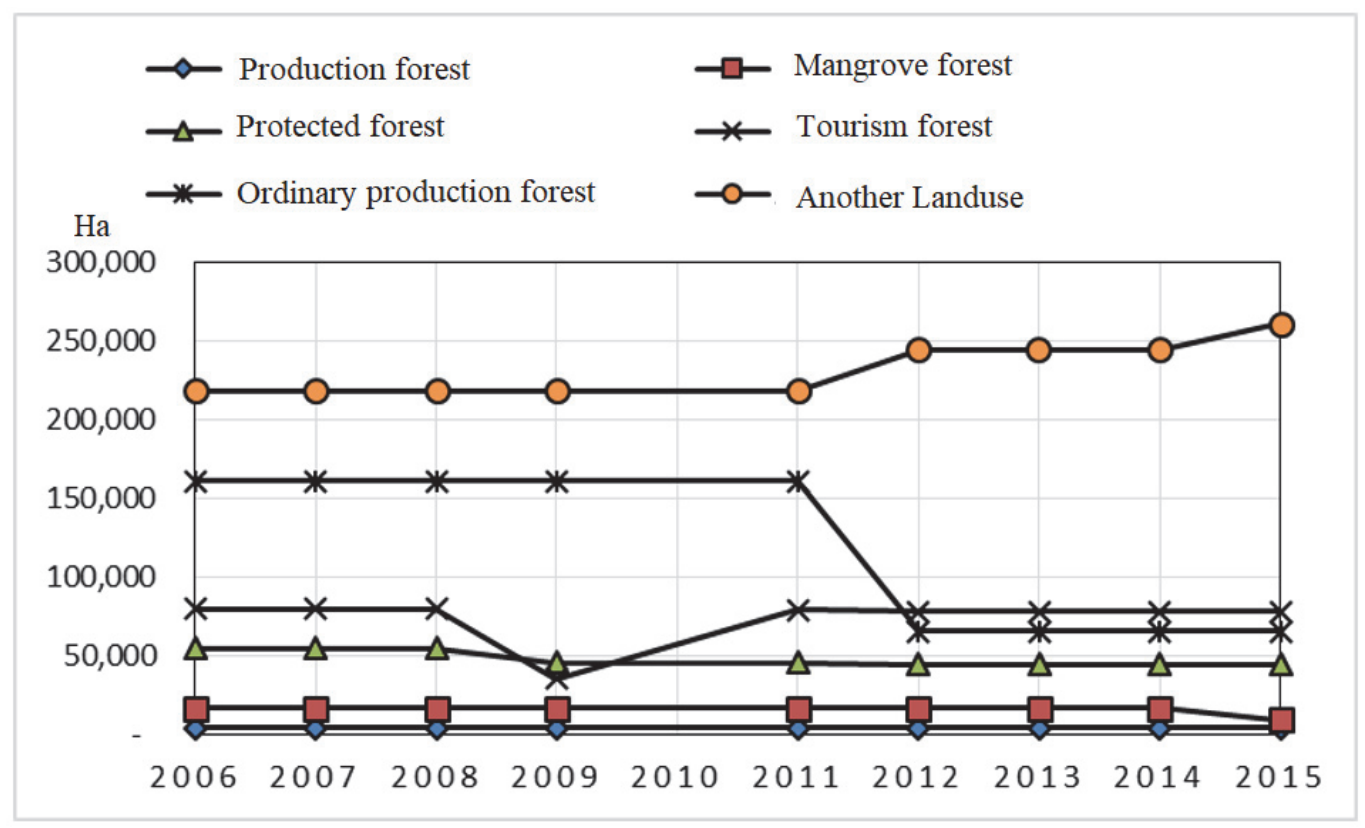

Figure 3. LULCC in South Konawe Regency (SE Sulawesi) according to South Konawe Statistic Agency year of 2010 to 2015 (source: BPS Konsel, 2016).

To increase the amount of carbon sequestration, GICS must become a role in forestry sector planning activities. Forestry planning is carried out through spatial planning of forest areas by taking into account the functions of the area, for example, the protected forests, peatlands, wetland, national park and so on to increase the amount of carbon sequestration, while at the same time reducing the level of disaster vulnerability in the surrounding area.

LULCC in SE Sulawesi is most caused by mining activities such as gold, nickel and asphalt. Since it was designated as a special economic mining area in Indonesia, nickel mining activities grew up to more than 20 million tons of nickel production in 2018 (BPS Sultra, 2019). Conversion of the forested area into the mining zone has became a high pressure for the environment.

Mapping and monitoring carbon stocks using remote sensing satellites provides a wide perspective of carbon stocks density and spasio-temporal characteristics. Figure 4 shows the distribution of carbon stocks volume in Rawa Aopa Watumohai National Park (RAWNP) in SE Sulawesi based on 2017 Landsat Satellite image. RAWNP has used satellite imagery to obtain periodic information about carbon stocks and land cover changes in more than 20 years (Jaya et al, 2019). One of the advantages of using satellite imagery is that it is widely available and can be obtained freely from an international satellite image database such as USGS (United States Geological Survey) database. 


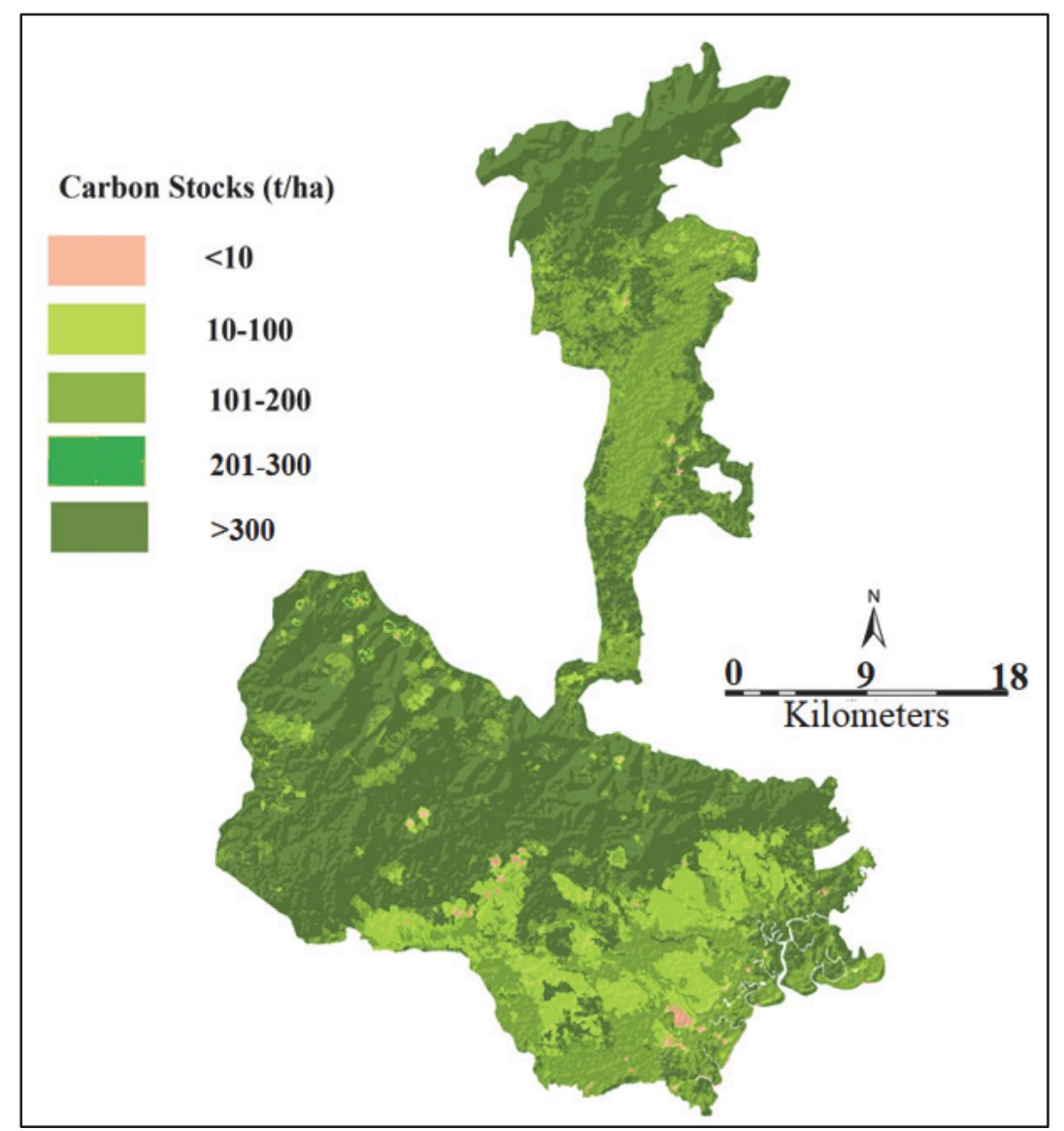

Figure 4. Distribution of carbon stocks volume in Rawa Aopa Watumohai National Park in SE Sulawesi based on Landsat Satellite image (Jaya et al, 2019)

\subsection{Environmental Protection}

The GICS also needs to be introduced into environmental protection and management. It is close relations between forestry, environmental protection and urban planning. In Indonesia, based on Environmental Act No. 32 the Year of 2009, each development program needs a Strategic Environmental Assessment (SEA). It means that all physical development programs particularly changing land use and land cover must be based on the environmental assessment to avoid a negative impact to the environment.

To support the SEA, the government needs to consider the carbon stocks information in the context of the Low Emission Development Strategy (LEDS) (Clapp et al., 2010). Figure 4 can be able to give information about the spatio-temporal of vegetated and non-vegetated area characteristics. The carbon stock value can become input for decision making by the government whether a particular environment needs to be secured. The development cannot be avoided, but the most important that the development going in accordance with low emission strategy by considering the carbon stocks spasio-temporal characteristics.

In SE Sulawesi, since 2017 the government has implemented the LEDS program to assess the capability and readiness of the regencies to protect their environment and at the same time increase the development in all sectors. Thus, LEDS becomes a starting point to achieve sustainable development with an emphasis on efforts to reduce as much as possible the occurrence of carbon emissions in the development process. Through the LEDS, a country or region can prepare its economic development strategy in the framework of supporting climate change mitigation (Clapp et al., 2010). This also can be done through regional spatial planning and implementation that prioritizes environmental interests and the principles of sustainable development in development planning (Susandi et al., 2014). Therefore, identification of the factual conditions of the region, particularly the carbon stocks spatiotemporal, is the main requirement to guarantee the success of the LEDS. 


\subsection{Spatial Planning}

To maintain the preservation of environmental functions and community safety, each spatial planning must be based on a Strategic Environmental Assessment (SEA) (Article 19 Paragraph (1) of the Environmental Act 2009). The statement is certainly closely related to Spatial Planning Act No. 26 the Year of 2007. Spatial planning is one of the fields that require the GICS.

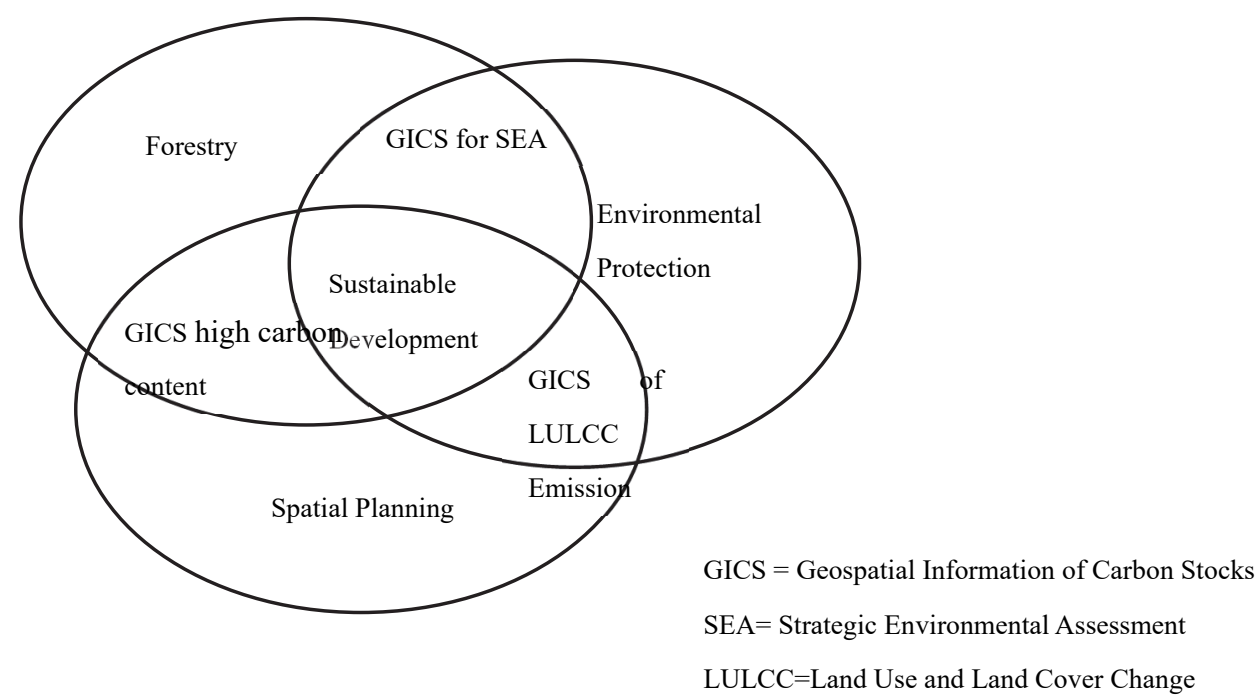

Figure 5. GICS positioning in the forestry, environmental protection, and spatial planning as a strategy for sustainable development (Jaya, 2017)

Figure 5 shows the GICS positioning in the management of forestry, environmental protection, and spatial planning as a strategy for sustainable development. It can be said that the inclusion of GICS in spatial planning is a manifestation of the implementation of Perpres 71 of 2011 concerning the National GHG Inventory (Setneg RI, 2011b). Therefore, the preparation of National, Provincial and Regency/City Spatial Plans should pay attention to carbon emission factors within the spatial area. In general, spatial planning contains the optimum technical aspects of land use zoning by considering aspects of population, land needs, environment, and economic growth.

In the context of reducing GHG emissions by $26 \%$ and added $15 \%$ (to $41 \%$ ) in accordance with the mandate of Perpres 61 and 71 of 2011, the government, the community and the business community are obliged to work to reduce GHG emissions, especially from the peatland forestry sector which contributes to GHG emissions by $87.6 \%$ of total GHG emissions in Indonesia. Therefore, Perpres 71 of 2011 mandates the need to develop carbon Monitoring, Reporting and Verification (MRV) schemes with good, reliable, and transparent accuracy (Setneg RI, 2011b). The GICS is one of the efforts to carry out the mandate of Perpres 71 of 2011 and the regulation which was discussed earlier.

Efforts to reduce GHG are one of the implementations of Article 17 Paragraph (5) of the Spatial Planning Act which states that in the framework of environmental preservation, in the regional spatial plan the forest area is determined to be at least $30 \%$ the watershed area. This statement is closely related to the GICS. This means that the GICS is needed to guarantee the extent of the proportion of forest area, which of course with an adequate level of carbon volume, as desired by the Act can be fulfilled. Thus, not only the extent, but also the volume of carbon in the watershed area can also be monitored and guaranteed its sustainability in accordance with the spirit of the REDD+ (Reducing Emissions from Deforestation and Forest Degradation, Plus Concervation) (FAO, 2017).

When examined deeply, the statement of Article 3 of the Spatial Planning Act is in line with the two previously discussed regulations namely the forestry act as well as the environment act 2009. All three regulations have slices on the same principle, namely sustainable development, as shown in Figure 5. The principle of sustainable development must, of course, be supported by accurate data and information in accordance with the objectives of sustainable development. One aspect of achieving sustainable development is the reduction of GHG emissions in the context of climate change mitigation. GICS in this case functioning in the SEA study of forestry management 
and environmental protection. In line with this, for forestry management and spatial planning, the GICS functioning to determine the proportion of $30 \%$ of forest area in the watershed as stated in the Spatial Planning Act. Moreover, the correlation of environmental protection and spatial planning where the GICS determining the LULC emissions must be well considered.

\section{Conclusion}

This paper has discussed the use of geospatial information of carbon stocks (GICS) for forestry management, environmental protection, and spatial planning with the case study in SE Sulawesi Indonesia. From the perspective of sustainable development, carbon stock information becomes one of the important geospatial information as stated in Indonesia Geospatial Act 2011. The GICS plays an important role to reduce GHG through LEDS analysis. The GICS is needed to guarantee the extent of the proportion of forest area, which of course with an adequate level of carbon volume, as desired by the Spatial Planning Act can be fulfilled. Thus, not only the extent, but also the volume of carbon in the watershed area can also be monitored and guaranteed its sustainability in accordance with the REDD + spirit.

\section{References}

Balitbang (Badan Penelitian dan Pengembangan Kehutanan). (2013). Pedoman Penggunaan Model Allometrik untuk Pendugaan Biomass dan Stok Karbon Hutan di Indonesia, Peraturan Kepala Badan Penelitian dan Pengembangan Kehutanan No. P.01/VIII-P3KR/2012, Ministry of Forestry of the Republic of Indonesia, ISBN: 978-979-3145-97-6

BPS Konsel (Badan Pusat Statistik Kabupaten Konawe Selatan/South Konawe Statistic Agency). (2016). Kabupaten Konawe Selatan Dalam Angka 2016, Publication of Statistic of South Konawe Regency.

BPS Sultra (Badan Pusat Statistik Provinsi Sulawesi Tenggara/SE Sulawesi Statistic Agency). (2019). Sultra Dalam Angka 2019, Publication of Statistic of Southeast Sulawesi Province.

BSN (Badan Standardisasi Nasional). (2011). SNI 7725: 2011 tentang Penyusunan persamaan alometrik untuk penaksiran cadangan karbon hutan berdasar pengukuran lapangan (ground-based forest carbon accounting), ICS 65.020

Clapp, C., Briner, G., \& dan Karousakis, K. (2010). Low-Emission Development Strategies (LEDS): Technical, Institutional and Policy Lessons, OECD. COM/ENV/EPOC/IEA/SLT, 2.

Dewi, R. G. (2012). Indonesia Low Carbon Development Strategy Scenario 2050: Energy Sector, the 4th AUN/SEED-Net Regional Conference on Global Environment and Seminar of NRCT- JSPS Asian Core Program.

Dewi, R. G., Siagian, U., \& dan Boer, R. (2012). Indonesia Low Carbon Emission Development Strategy Scenario 2020 and 2050 in Energy Sector, Proceedings the 18th AIM Workshop National Institute for Environmental Studies-Japan, 14-16 December 2012.

FAO (Food and Agricultural Organization). (2017). Forests and Climate Change Working Paper 15, From reference levels to results reporting: REDD+ under the UNFCCC.

IPCC. (2007). Climate Change 2007: Mitigation. Contribution of Working Group III to the Fourth Assessment Report of the Inter-governmental Panel on Climate Change, B. Metz, O.R. Davidson, P.R. Bosch, R. Dave, L.A. Meyer, ed., Cambridge University Press, Cambridge, United Kingdom and New York, NY, USA., pp. 541-584

Jaya, L. M. G., Masse, D. C. A., \& Saleh, F. (2019). Studi Cadangan Karbon Vegetasi Mangrove Dalam Taman Nasional Rawa Aopa Watumohai Sulawesi Tenggara. Physical and Social Geography Research Journal, 1(1).

Jaya, L. M. G. (2017). Estimation of Carbon Stocks using Radar Polarimetric in the perspective of climate change mitigation (case study: Southeast Sulawesi Province), Ph.D. Dissertation, Institut Teknologi Bandung, Indonesia.

Sadaf, R., Ramoelo, A., Nabi khan, R.Z., Younes, I., Zafar, H., (2019). Quantitative Assessment of Hab Watershed Using Geoinformatics. Land Science, 1(1). https://doi.org/10.30560/1s.v1n1p1

Sekretariat Negara Republik Indonesia (Setneg RI). (2009). Undang-Undang No. 41 Tahun 2009 tentang Kehutanan.

Sekretariat Negara Republik Indonesia (Setneg RI). (2011a). Peraturan Presiden No. 61 Tahun 2011 tentang Rencana Aksi Nasional Pengurangan Gas Rumah Kaca (GRK). 
Sekretariat Negara Republik Indonesia (Setneg RI). (2011b). Peraturan Presiden No. 71 Tahun 2011 tentang Inventarisasi Gas Rumah Kaca Nasional.

Sumargo, W., Nanggara, S. G., Nainggolan, F. A., \& dan Apriani, I. (2011). Potret Keadaan Hutan Indonesia Tahun 2000-2009, Edisi Pertama, Forest Watch Indonesia, ISBN: 978-979-96730-1-5.

Susandi, A., Hakim, S., \& Melany, J. (2014). Low-Emission Development Strategy in Katingan Regency. No. 42444183/SPRE/1.0, URS Australia Pty Ltd.

\section{Copyrights}

Copyright for this article is retained by the author(s), with first publication rights granted to the journal.

This is an open-access article distributed under the terms and conditions of the Creative Commons Attribution license (http://creativecommons.org/licenses/by/4.0/). 